\title{
Caribbean Reef Drowning During Slow Mid-Holocene Sea-Level Rise
}

\author{
Paul Blanchon ${ }^{1 *}$, José Estrada ${ }^{2}$, Simon Richards $^{3}$, Juan-Pablo Bernal ${ }^{4}$, Sergio \\ Cerdeira-Estrada ${ }^{5}$ Raúl Martell-Dubois ${ }^{5}$
}

${ }^{1}$ Unidad de Sistemas Arrecifales (Puerto Morelos), Instituto de Ciencias del Mar y Limnología, Universidad Nacional Autónoma de México, A.P. 13, Cancun, Quintana Roo, C.P. 77500, Mexico. ${ }^{2}$ Unidad de Sistemas Arrecifales (Puerto Morelos), Posgrado en Ciencias del Mar y Limnología, Universidad Nacional Autónoma de México, A.P. 13, Cancun, Quintana Roo, C.P. 77500, Mexico. ${ }^{3}$ Member, Churchill College, Cambridge, CB3 0DS, United Kingdom. ${ }^{4}$ Lab. de Estudios Isotópicos, Centro de Geociencias, Universidad Nacional Autónoma de México, Campus UNAM-Juriquilla, Querétaro 76230, México. ${ }^{5}$ Comisión Nacional para el Conocimiento y Uso de la Biodiversidad (CONABIO), Av. Liga Periférico-Insurgentes Sur 4903, Parques del Pedregal, Tlalpan, 14010, Ciudad de México.

*Correspondence and requests for materials should be addressed to P.B. (blanchons@gmail.com)

\begin{abstract}
Predicting if reefs can keep pace with future sea-level (SL) rise is problematic because accretion occurs over geological timescales. For example, although meltwater pulses drowned reefs during postglacial SL rise, drowning has also been reported during the mid Holocene, when SL rise was slower and meltwater pulses unlikely. Here we report the discovery of a drowned incipient reef-crest on the widest part of northeast Yucatan shelf. Our data show the reef is an array of closely-spaced patches that crest at $-14 \mathrm{~m}$. These patches consist of $3 \mathrm{~m}$-thick stands of Acropora palmata that grew over a Pleistocene dune ridge $\sim 8 \mathrm{ka}$ ago, but subsequently failed to keep pace with rising SL. We hypothesize that this failure is due to the suppression of coral recruitment by high sediment flux on wide shelves. Although recruitment does occur as the surf zone crosses topographic residuals during the transgression, suppression in sandy reef-fronts and back-reefs limits accretion of these incipient crests, causing their slow drowning during SL rise. We conclude that although reefs can slowly develop breakwaters in such settings, they may be incapable of vertical accretion and thus vulnerable to drowning. Identifying reefs with this vulnerability will be key to managing future SL rise.
\end{abstract}




\section{Introduction}

Coral reefs produce linear breakwaters that play a key role in protecting tropical coasts from high-energy wave events generated by storms or tsunamis ${ }^{1}$. To retain this breakwater function, reefs must accrete vertically at a rate that matches or exceeds that of relative $\mathrm{SL}$ rise ${ }^{2}$. With an increasing rate of $\mathrm{SL}$ rise $^{3}$, metre-scale projections of future $\mathrm{SL}$ rise $^{4}$ and declines in reef health ${ }^{5}$, there is considerable uncertainty about the potential of reefs to match these rises and hence continue to protect coastlines from wave erosion ${ }^{6}$.

A significant part of this uncertainty relates to quantifying long term reef-accretion rates. Accretion is mediated by processes that occur on both ecologic and geologic timescales. Over shorter ecologic timescales, accretion is controlled by coral growth rate, productivity and bioerosion ${ }^{7}$, which vary both biogeographically and also due local changes in wave exposure, slope, and sediment flux ${ }^{8}$. Over longer timescales accretion is modified by tropical cyclones, which locally destroy and reposition shallow-coral on a regular basis over thousands of years ${ }^{9}$. As a result, reefs show significant spatial variation in accretion rates, implying that there maybe a subset of reefs with low accretion potentials that are naturally vulnerable to future global climate and SL changes ${ }^{10}$

A geologic approach to identifying reefs with low accretion potentials is to investigate those that drowned during postglacial SL rise. In the Caribbean-Atlantic reef province, drowned reefs have been discovered at several locations ${ }^{11}$ based on the presence of submerged crests composed of monospecific frameworks of $A$. palmata, which only develop in the surf/breaker zone less than $5 \mathrm{~m}$ deep ${ }^{12}$. Most of these reef crests drowned during accelerations in SL rise known as meltwater pulses, which resulted from rapid deglaciation of northern Hemisphere ice sheets ${ }^{13,14,15}$. Yet recent reports ${ }^{16}$ of reef-crest drowning during the mid-Holocene (4-8 ka), when SL and ice sheets had begun to stabilize close to their present positions, suggest that meltwater pulses are unlikely to be the cause. In these cases, changes in local climate or sub-optimal environmental conditions may have suppressed the accretion potential of reefs so that they could not keep pace with gradually rising SL. Investigating mid-Holocene reef drowning may therefore help identify natural environmental causes of low accretion and the subset of modern reefs that may be at risk of drowning.

\section{Results}

To investigate the cause of mid-Holocene reef drowning, we searched for submerged relict reef-crests along the northeast-Yucatan section of the Mesoamerican Reef tract, which is developed over a 3-4 km wide sand-covered shelf ${ }^{17}$. A semi-continuous reef ridge was discovered between the 18-14 $\mathrm{m}$ isobaths along the inner part of this shelf (Fig. 1). To document the morphology of this feature we mapped the sea floor bathymetry over a $\sim 1 \mathrm{~km}$ section with an area of 10 ha at sub-meter vertical resolution (Methods). These data show an irregular asymmetrical ridge that parallels the modern reef higher up-slope (Fig. 1B). The width of the reef is irregular and varies from 70 to $130 \mathrm{~m}$. It has a relief of $\sim 5 \mathrm{~m}$ and rises sharply from a sand-covered terrace at a depth of $\sim 18 \mathrm{~m}$, levelling off to form a crest at $\sim 14 \mathrm{~m}$, before sloping steeply back down to $16 \mathrm{~m}$ on its landward side. The maximum relief of the ridge is $6 \mathrm{~m}$ along the northern part, due to lower sand accumulation on its landward side, and the development of isolated peaks on the crest that reach depths of $12 \mathrm{~m}$ (Fig. 1C). The size of the ridge is thus comparable to the modern reef in shallower water which forms a tract $\sim 130 \mathrm{~m}$ wide, but does not share the same variations in width and height. 

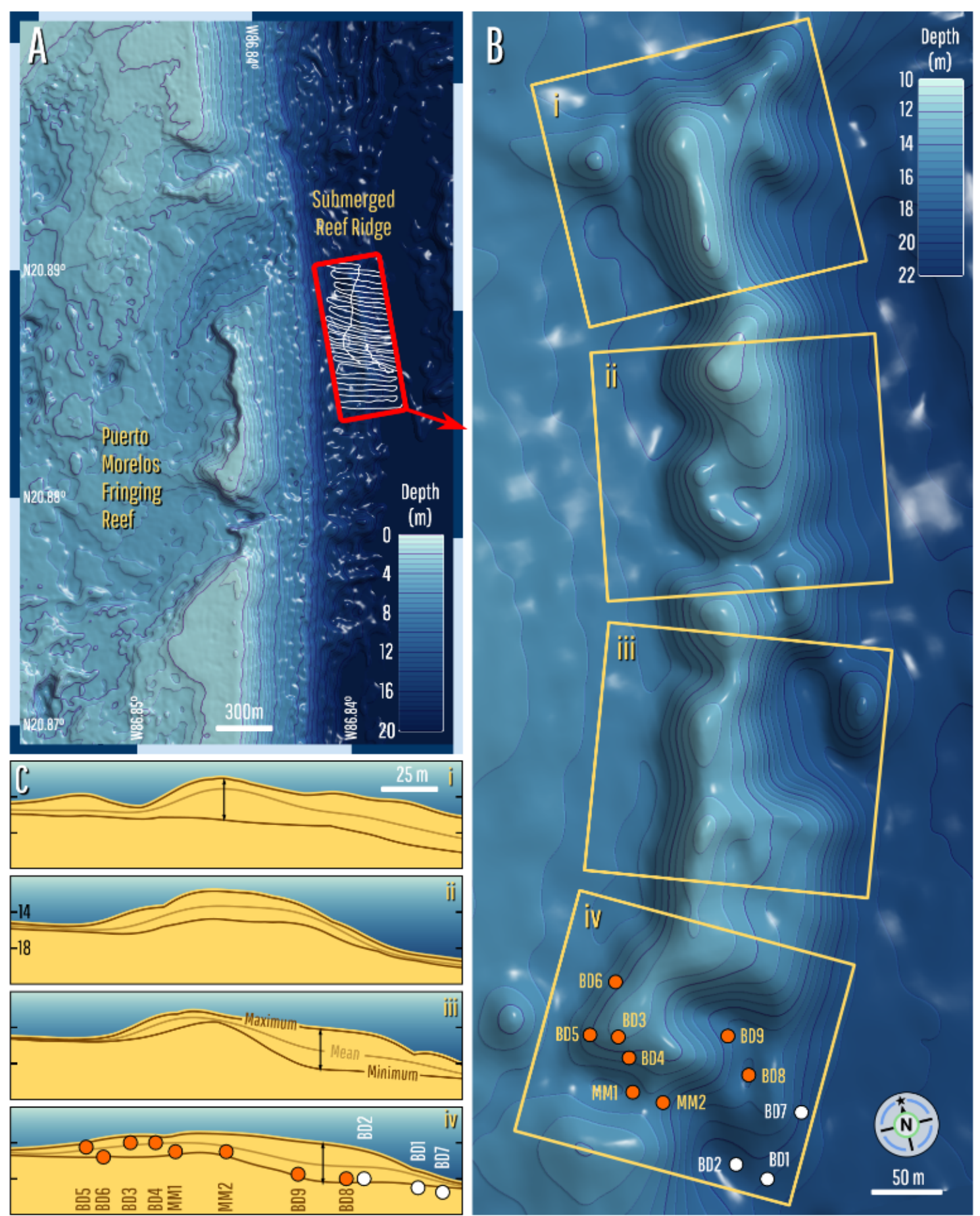

Figure 1. Configuration and morphology of submerged reef ridge. (A) Bathymetry of the Mesoamerican Reef off Puerto Morelos, NE Yucatan (centered on $20.878186^{\circ}-86.844745^{\circ}$ ), showing the modern reef along inner part of a 3-km wide sandy terrace. Inset shows location of submerged reef ridge and depth-sounder tracks. (B) Bathymetric reconstruction of reef ridge shows it consists of a linear series of closely-spaced patches which crest at $-14 \mathrm{~m}$ (contour interval $0.5 \mathrm{~m}$ ). Note location of $A$. palmata samples (orange circles) and underlying Pleistocene dune (white circles). (C) Depth profiles generated from boxed areas in panel B, along the reef ridge, showing the minimum, mean and maximum depth profiles in each area (Methods). Profiles show an $\sim 5 \mathrm{~m}$ maximum relief (arrow) which likely reflects the amount of reef accretion developed over the Pleistocene substrate.

To establish the age and composition of the ridge, and its underlying substrate, core and surface samples were taken from sub-vertical surfaces where reef framework was 
visible (Methods). Three short core-samples were taken from substrates on the front slope of the ridge below the $18 \mathrm{~m}$ isobath (BD1,2 and 7: Fig. 1C). All consist of a well-sorted fine-grained carbonate sandstone (grainstone) with low-angle laminations typical of low-energy coastal dune or beach deposits. This interpretation is supported by the presence of micrite-filled rhizoliths which are consistent with root penetration by dune vegetation (Fig. 2A). These samples imply that the reef ridge grew over the apex of a relict coastal beach/dune ridge of late Pleistocene or early Holocene age.

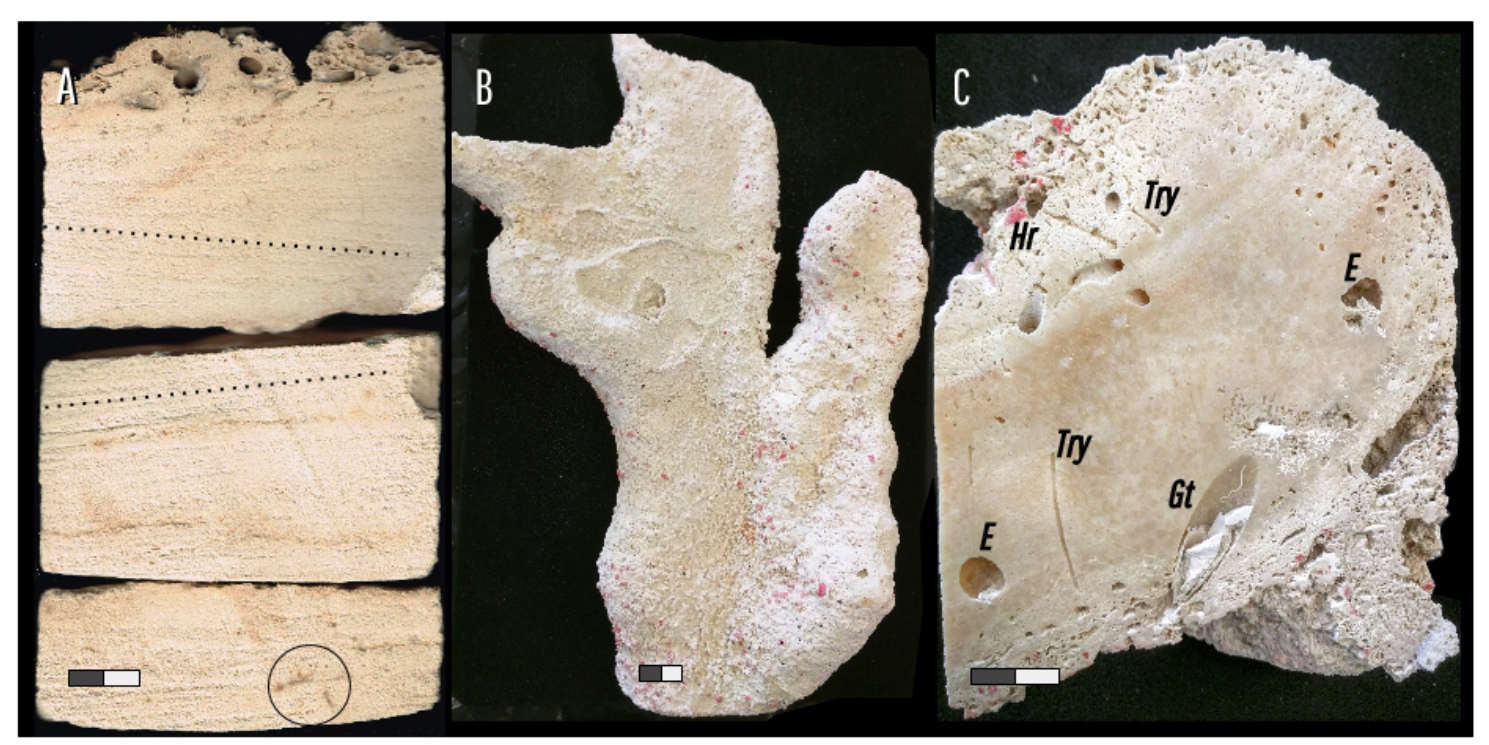

Figure 2. Submerged reef-ridge samples. (A) Core sample of Pleistocene dune substrate underlying reef ridge: highlighted are low-angle cross lamination (dashed lines) and micritic rhizoliths (solid circle). Scale in $\mathrm{cm}$. (B) Well preserved palmate-shaped clast of A. palmata, with little bioerosion or encrusting epibionts. (C) Core sample BD6 taken from an area of the reef with visible in-place A. palmata framework. Sample shows low-relief forms of Homotrema rubrum $(\mathrm{Hr})$, Entobia isp (E), Trypanites isp (Try) and Gastrochaenolites torpedo (Gt), all typical of the surf zone in shallow-reef environments ${ }^{18}$.

The other 8 short cores and samples consist of the reef-crest coral, A. palmata. Most of these were taken from surfaces dominated by loose or poorly consolidated cobble-sized clasts, which included intact branch fronds with palmate shapes and low levels of encrustation and bioerosion (Fig. 2B). These samples returned ${ }^{230} \mathrm{Th}$ ages between 6.8 and $6.1 \mathrm{ka}$ (Table 1). However the core sample BD6, which was taken from visibly in-place coral framework exposed beneath the ridge-crest, returned an older ${ }^{230} \mathrm{Th}$ age of $7.9 \mathrm{ka}$ (Table 1). This framework sample consists of a robust cylindrical branch of A.palmata that is associated with low-relief forms of Homotrema rubrum and macroboring ichnospecies such as Entobia isp, Trypanites isp, and Gastrochaenolites isp (Fig. $2 \mathrm{C})$. This suite of encrusters and bioeroders is consistent with taphonomically defined surf-zone environments $(<2-3 \mathrm{~m})$ from the reef-front and reef-crest facies ${ }^{18}$. 
Table $1 .{ }^{230} \mathrm{Th}$ age of coral samples

\begin{tabular}{|c|c|c|c|c|c|c|c|c|c|}
\hline $\begin{array}{l}\text { Sample } \\
\text { Species } \\
\text { Type }\end{array}$ & $\begin{array}{l}\text { Coords. } \\
\text { (Latitude/ } \\
\text { Longtitude) }\end{array}$ & $\begin{array}{l}\text { Recorded } \\
\text { Depth } \\
\text { (Interpolate } \\
\text { d depth) } \\
\text { (m) }\end{array}$ & $\begin{array}{c}{ }^{\mathbf{2 3 8}} \mathbf{U} \\
(\mathrm{ppm}) \\
+/-\end{array}$ & $\begin{array}{c}{ }^{230} \mathrm{Th} /{ }^{238} \mathrm{U} \\
+/-\end{array}$ & $\begin{array}{c}{ }^{234} U /^{238} \mathrm{U} \\
+/-\end{array}$ & $\begin{array}{c}\delta^{234} U \\
+/-\end{array}$ & $\begin{array}{c}{ }^{238} \mathrm{U} /{ }^{232} \mathrm{Th} \\
+/-\end{array}$ & $\begin{array}{c}\begin{array}{c}\text { Age } \\
\text { (Ka) } \\
+/-\end{array} \\
\end{array}$ & $\begin{array}{c}\delta_{+/-}^{234} U^{\circ} \\
+/\end{array}$ \\
\hline $\begin{array}{l}\text { PM-BD5 } \\
\text { A.palmata } \\
\text { Stump }\end{array}$ & $\begin{array}{l}516347 / \\
2308673\end{array}$ & $\begin{array}{c}14.5 \\
(14.0)\end{array}$ & $\begin{array}{l}3.094 \\
0.003\end{array}$ & $\begin{array}{l}0.0699 \\
0.0008\end{array}$ & $\begin{array}{l}1.1452 \\
0.0007\end{array}$ & $\begin{array}{c}145.2 \\
0.7\end{array}$ & $\begin{array}{c}5371 \\
34\end{array}$ & $\begin{array}{c}\mathbf{6 . 8 4} \\
0.075 \\
0.076\end{array}$ & $\begin{array}{c}148.1 \\
2.3\end{array}$ \\
\hline $\begin{array}{l}\text { PM-BD6 } \\
\text { A.palmata } \\
\text { Colony }\end{array}$ & $\begin{array}{l}516373 / \\
2308705\end{array}$ & $\begin{array}{c}15.6 \\
(14.4)\end{array}$ & $\begin{array}{l}3.168 \\
0.001\end{array}$ & $\begin{array}{l}0.0795 \\
0.0006\end{array}$ & $\begin{array}{l}1.1374 \\
0.0046\end{array}$ & $\begin{array}{c}137.4 \\
4.6\end{array}$ & $\begin{array}{c}12433 \\
44\end{array}$ & $\begin{array}{c}7.87 \\
0.073 \\
0.073\end{array}$ & $\begin{array}{l}141 \\
5.0\end{array}$ \\
\hline $\begin{array}{l}\text { PM-BD8 } \\
\text { A.palmata } \\
\text { Clast }\end{array}$ & $\begin{array}{l}516449 / \\
2308620\end{array}$ & $\begin{array}{c}18 \\
(17.1)\end{array}$ & $\begin{array}{l}3.037 \\
0.001\end{array}$ & $\begin{array}{l}0.0669 \\
0.0017\end{array}$ & $\begin{array}{l}1.1448 \\
0.0011\end{array}$ & $\begin{array}{c}144.8 \\
1.1\end{array}$ & $\begin{array}{c}8814 \\
172\end{array}$ & $\begin{array}{c}6.54 \\
0.170 \\
0.160\end{array}$ & $\begin{array}{c}147.5 \\
2.5\end{array}$ \\
\hline $\begin{array}{l}\text { PM-MM1 } \\
\text { A.palmata } \\
\text { Clast }\end{array}$ & $\begin{array}{l}516367 / \\
2308627\end{array}$ & $\begin{array}{c}15 \\
(15.4)\end{array}$ & $\begin{array}{l}3.560 \\
0.002\end{array}$ & $\begin{array}{l}0.0657 \\
0.0006\end{array}$ & $\begin{array}{l}1.1446 \\
0.0010\end{array}$ & $\begin{array}{c}144.6 \\
1.0\end{array}$ & $\begin{array}{c}13730 \\
124\end{array}$ & $\begin{array}{c}6.42 \\
0.058 \\
0.055\end{array}$ & $\begin{array}{c}147.2 \\
2.4\end{array}$ \\
\hline $\begin{array}{l}\text { PM-MM2 } \\
\text { A.palmata } \\
\text { Clast }\end{array}$ & $\begin{array}{l}516386 / \\
2308615\end{array}$ & $\begin{array}{c}15 \\
(15.5)\end{array}$ & $\begin{array}{l}3.122 \\
0.002\end{array}$ & $\begin{array}{l}0.0626 \\
0.0013\end{array}$ & $\begin{array}{l}1.1446 \\
0.0007\end{array}$ & $\begin{array}{c}144.6 \\
0.7\end{array}$ & $\begin{array}{c}1951 \\
33\end{array}$ & $\begin{array}{c}\mathbf{6 . 1 0} \\
0.130 \\
0.130\end{array}$ & $\begin{array}{c}147.2 \\
2.5\end{array}$ \\
\hline
\end{tabular}

These results are consistent with the brief development of an immature reef crest $\sim 8 \mathrm{ka}$ ago. The lack of a normal morphological zonation similar to the modern reef, together with the irregular surface morphology and the limited $5 \mathrm{~m}$ relief, suggests that the reef developed as a single, but patchy layer of $A$. palmata within its monospecific depth habitat of $0-5 \mathrm{~m}^{12}$. Furthermore, the presence of colonies with large cylindrical branches and surf-zone epibionts implies that the upper part of this layer developed within 2-3 $\mathrm{m}$ of the water surface. However, this immature reef-crest did not keep pace with SL rise and was slowly submerged. The presence of younger palmate-shaped clasts over parts of its surface signifies that, during this submergence, it was partially colonized by younger acroporids that grew in deeper water over a more extended period of time. These colonies did not remain in place, however, and their clasts filled depressions in the irregular surface of the ridge.

The interpretation that deeper-water corals later colonized an inactive reef crest, can be tested by comparing their age-elevation data against independent SL curves, as illustrated in Figure 3. 


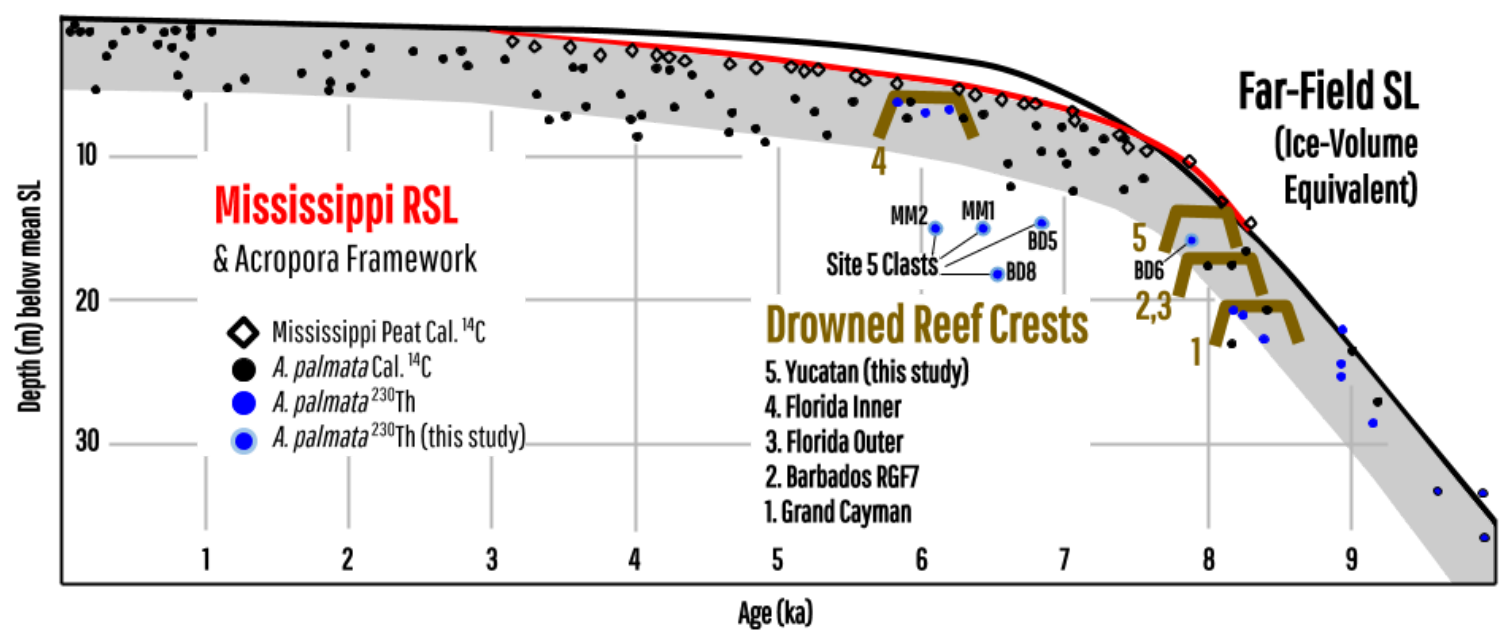

Figure 3. Drowned reef crests and Holocene SL rise. Comparison between a local relative SL curve from the Mississippi Delta ${ }^{19}$ (red curve) and ice-volume equivalent far-field $\mathrm{SL}^{20}$ (black curve). The Mississippi peat curve caps age-elevation data from in-place monospecific A. palmata framework $^{11,18,21,22}$ (grey band). Positions of drowned reefs reported ${ }^{11}$ from Grand Cayman, Barbados, and Florida are shown superimposed over these SL data. Position of incipient reef-crest reported here (site 5 ) shows that it developed within $3 \mathrm{~m}$ of mean SL $\sim 8 \mathrm{ka}$ ago. Plotting the age-elevation data of the younger clasts from its surface show that, when they grew $\sim 6-7 \mathrm{ka}$ ago, the incipient reef crest was in 8-9 $\mathrm{m}$ of water (3-4 m below the monospecific habitat range).

This figure shows that a local relative SL curve reconstructed from Mississippi basal peats ${ }^{19}$ is similar to ice-volume-equivalent SL derived from far-field data corrected for glacio-isotatic adjustment ${ }^{20}$, with only a minor 2-3 $\mathrm{m}$ offset in magnitude that could be attributed to local glacio- or hydro-isostatic processes. The Mississippi curve caps age/depth data from Caribbean reef-crest framework ${ }^{11,18,21,22}$, and the position of drowned reefs ${ }^{11}$, confirming the 0-5 m monospecific depth habitat for A. palmata $^{12}$. By superimposing our ${ }^{230} \mathrm{Th}$ age/depth data on this reconstruction, it is clear that the $7.9 \mathrm{ka}$ framework sample from the immature reef crest (BD6) developed within the normal 0-5 $m$ depth habitat of modern reef-crest corals (shown by the grey band in Fig. 3),

supporting the interpretation that it formed in the surf zone. But when the younger clasts grew $\sim 6-7 \mathrm{ka}$ ago (shown as clasts in Fig. 3), the reconstruction shows that the incipient reef crest was submerged in 8-9 m of water, some 3-4 m below the monospecific depth habitat, supporting the interpretation that they grew on, and were later deposited over, an inactive or drowned reef crest.

\section{Discussion}

The comparison with SL supports our claim that a single stand of $A$. palmata initiated reef-crest development close to sea level $\sim 8 \mathrm{ka}$ ago. Although our data do not allow an assessment of accretion rates per se, it is clear from the limited thickness and irregular morphology, that the stand of Acropora underwent little vertical accretion. The failure to accrete and extend outside its biological habitat shows that, when it drowned, the reef crest was at an incipient stage of development ${ }^{23}$. The key question is why this incipient reef crest was unable to develop further and keep-up with SL rise? There are two main possibilities: first, SL rise was too fast to allow reef-crest development or, second, reef accretion was suppressed by environmental factors.

Considering the first possibility, there are several reports of reef-crest drowning in the Caribbean during postglacial SL rise ${ }^{11,13,16,24-26}$. The drowning of these reefs have been associated with pulses of meltwater discharge that produced brief accelerations in postglacial SL rise ${ }^{13,14}$. Several reports, for example, have linked the demise of fully 
developed and actively accreting early Holocene reefs to an acceleration in the rate of SL rise centered around $\sim 8.4$ ka ago, produced by the final disintegration of the Laurentide Ice Sheet ${ }^{11,27,28}$. Rise rates during these pulses have been estimated at $\sim 40$ $\mathrm{mm} / \mathrm{yr}$ or more ${ }^{11,13,15,29}$ and have been corroborated by dating of basal-peat sequences from coastal marshes and mangroves ${ }^{19,30}$. Nevertheless, such pulses caused only brief cessations in reef development, and reef crests back-stepped to locations further up-slope as soon as the rate of rise had returned to previous levels. Indeed, during nearly the entire postglacial SL rise, reef-crests in some areas kept pace with rise rates of 10-12 $\mathrm{mm} / \mathrm{yr}$, producing vertically accreting sequences of $A$. palmata framework as thick as $30 \mathrm{~m}$ in less than $3 \mathrm{ka}^{13,29,31}$.

In the case of our incipient reef, Figure 3 shows that it postdates any meltwater pulse centered at $8.4 \mathrm{ka}$, which was likely responsible for drowning actively-accreting Caribbean reefs ${ }^{11}$. And in the thousand-year interval following its initiation at $\sim 8 \mathrm{ka}$, the reconstructions show SL rose at a rate of only $\sim 7 \mathrm{~mm} / \mathrm{yr}$. As a consequence, it is unlikely that SL rise was too fast to permit reef-crest development, and more likely that it drowned due to suppression of reef-accretion rates. The question therefore becomes what environmental conditions can simultaneously allow reef communities to initiate, yet suppress their vertical accretion on geological timescales as SL rises?

Considering the second possibility, several studies have reported climatic cooling as a possible environmental factor causing reef demise. Along the Pacific coast of Costa Rica, for example, radiometric dating of several dead reefs returned radiocarbon ages of $\sim 600-700$ years $^{32}$. Although subtracting a $465 \mathrm{yr}$ marine-reservoir age gave dates that coincided with the Little Ice Age, the reservoir age in this area is now known to range between 260-560 yrs due to upwelling ${ }^{33}$, giving low confidence in the timing of reef demise and it's postulated Little Ice Age cause. Cooling-induced reef demise has also been postulated following the discovery of a mid-Holocene drowned reef in Florida ${ }^{16}$. Exposed in a trench formed by a submarine grounding, the reef consisted of a single stand of A. palmata framework with calibrated radiocarbon ages between 6.8-7.4 ka (inner reef of ref. 12). LIDAR data showed the stand had a crest at $\sim 8 \mathrm{~m}$ and was essentially an amalgamation of patch reefs that formed a linear structure ${ }^{16}$. Later drilling confirmed these data and suggested that reef development terminated at $\sim 6$ ka possibly as a result of climate cooling following the end of the Holocene Thermal Maximum ${ }^{34}$.

The morphological similarity between the inner Florida structure and the incipient reef crest reported here is striking. They both initiated development over topographic highs on wide sandy shelves, both formed single stands of Acropora aligned in irregular patches, and both failed to undergo any significant vertical accretion. Given the tropical location of one, and differences in the timing of their demise, we suggest that neither of these incipient reefs were terminated by climatic cooling but, instead, simply failed to develop as a result of the generally unfavourable conditions for reef accretion on wide sandy shelves ${ }^{9,35}$. We hypothesize that on such wide low-gradient shelves, recruitment of Acropora is suppressed due to high sediment flux ${ }^{36}$ and only occurs sporadically when topographic highs are inundated during the transgression. In our case, the apex of a Pleistocene dune ridge provided a suitable substrate for coral recruitment because it trapped and removed sand from the surf-zone and therefore afforded the recruits relief from wave-suspended sediment. However, the lack of recruitment in adjacent sandy back-reef and reef-front zones suppressed the accretion potential of the incipient reef crest and prevented a full breakwater structure from developing. Thus, as slow SL rise continued, the Acropora stand was left to slowly drown. 
This suppressed-accretion hypothesis can therefore account for the drowning of incipient reefs on wide sandy shelves during slow Holocene SL rise. This model can be tested because it predicts that reef development is dependent on the geomorphology of the shelf ${ }^{17}$. As a consequence, reef crests that drown on wide shelves with high sediment flux should therefore survive in areas where the shelf is narrower. More importantly, the model implies that reefs can initiate and perhaps develop in suboptimal environments where only low rates of accretion are possible. The repercussion of suppressed accretion is that there maybe modern reefs that were only able to develop slowly during the last 7 $\mathrm{ka}$ when SL rise was minimal (rising only $4-5 \mathrm{~m}$ at rates of $<3 \mathrm{~mm} / \mathrm{yr}$ ). If true, then the order-of-magnitude increase in the rate of SL rise predicted to occur by the end of the Century ${ }^{4,37}$ means that such reefs would be unable to keep pace and drown. The possibility exists, therefore, that a subset of modern reefs may be inherently vulnerable to drowning, even if their condition can be restored to a pristine state of health ${ }^{38,39}$. Identifying which reefs are vulnerable, however, will require a more detailed analysis of their chronological structure so that the timing and rates of lateral accretion and breakwater-reef development can be quantified. Failure to identify this vulnerability may compromise the protection of coastal zones dependent on reefal breakwaters.

\section{Methods}

Bathymetry

General bathymetric data for the shelf down to $\sim 15 \mathrm{~m}$ was derived from satellite imagery ${ }^{40}$. To delineate the morphology of the submerged reef ridge, we collected additional depth/position data using a Garmin GPSMAP 178C single-beam Sounder. To minimise error due to wave-induced sensor movement, we ran profiles during calm sea-surface conditions with minimal wave activity. In total, 32 depth transects were run perpendicular to the long axis of the reef structure, spaced approximately $25 \mathrm{~m}$ apart, with sonar data points recorded every $\sim 6 \mathrm{~m}$ along the transects, generating a total of 2800 distinct data points. A gridded digital elevation model (DEM) at a sample spacing of $\sim 9 \mathrm{~m}$ was produced by localised ordinary kriging of the sonar data with a linear variogram, using Surfer version 13.3.493. For comparison, a similarly gridded DEM was produced using Global Mapper version 10.02, which uses simple bilinear interpolation over a triangulated mesh. Graphics and interpolated depths were derived by convolution of the gridded DEM with a linear filter. The filter kernel was dynamically instantiated at each interpolation point, taking into account the relative positions of the interpolation point and the contributing sample points, with a radius of $20 \mathrm{~m}$ chosen to remove visible artifacting. The filter has strictly no overshoot and hence is unable to generate minima or maxima absent in the input data, and responds from $10 \%$ to $90 \%$ of a step input over a distance of $17 \mathrm{~m}$. After filtering, the results from both gridding methods were visually indistinguishable. The depths at each of the 2800 sonar points were interpolated from the filtered kriged DEM and compared with the originally recorded depths, with mean and root mean square (RMS) errors being 1.8 $\mathrm{mm}$ and $23 \mathrm{~cm}$. The standard deviations of the recorded and interpolated depths over the 2800 sonar points were $2.43 \mathrm{~m}$ and $2.39 \mathrm{~m}$, consistent with our filtering having had little impact on the data. Boxes in Figure 1(b) show areas used to generate profiles $i$ to iv. For each profile we plotted the minimum, arithmetic mean and maximum elevation above the baseline of the box.

\section{Sampling}


To establish the composition and age of the reef feature, and its underlying substrate, surface samples were taken from vertical and sloping surfaces where reef framework was visibly exposed. Samples from large in-place coral colonies, or their substrate, were taken with either a 3-speed hydraulic drill unit and a $12 \mathrm{~cm}$ diameter core barrel, or a portable pneumatic drill with a $5 \mathrm{~cm}$ diameter core barrel. Using these drills, core samples were collected up to $\sim 50 \mathrm{~cm}$ into the reef and underlying substrate. This surface sampling approach can be more reliable at identifying in-place corals than vertical drill cores where there can be considerable uncertainty in distinguishing in-place framework from large detrital clasts ${ }^{18}$. Sample depths were measured using a scuba depth gauge. Comparison of recorded depths with interpolated sonar depths at 11 sample points gave a mean difference of $0.4 \mathrm{~m}$ (depth gauge deeper), an root-mean-square error of $0.79 \mathrm{~m}$, and a maximum difference of $1.38 \mathrm{~m}$ (BD7, depth gauge deeper). At the average sample depth of $16 \mathrm{~m}$, gauge miscalibration between freshwater and seawater will give rise to $0.4 \mathrm{~m}$ reported depth variation (an instrument calibrated for freshwater reporting a deeper physical depth). Tides are also a source of error and are mainly within $\pm 10 \mathrm{~cm}$ of mean at this location but, in conjunction with geostrophic effects from the Yucatan Current and possible wind effects, ocean level may vary by several $\mathrm{dm}$ at extrema ${ }^{41}$.

\section{Dating}

The samples were dated by isotope-dilution MC-ICPMS using a Thermo-Finnigan Neptune Plus at Centro de Geociencias, UNAM, using a high-purity ${ }^{229}$ Th spike obtained from Oakridge National Laboratory, and ${ }^{233} \mathrm{U}$ from IRMM 051a reference material $^{42}$. All sample preparations were carried out in a class 100 clean-lab, with blanks typically lower than $3 \mathrm{pg}$ of ${ }^{238} \mathrm{U}$ and $1 \mathrm{pg}$ of ${ }^{232} \mathrm{Th}$. Uranium and Thorium were measured independently. ${ }^{234} \mathrm{U}$ was measured with an ion-counter (SEM) behind a retardant potential quadrupole (RPQ) filter, providing an abundance sensitivity of 0.5 ppm at m-1 which, nevertheless, is unable to fully remove the tailing contributions from ${ }^{238} \mathrm{U}$ and ${ }^{235} \mathrm{U}$ upon ${ }^{234} \mathrm{U}$. Consequently, we added a fast magnet jump in the measurement routine to monitor at $\mathrm{m} / \mathrm{Z}+=233.5$ and 234.5 on the SEM and remove any contribution by linear interpolation. ${ }^{230} \mathrm{Th}$ was measured with the SEM behind the RPQ filter. Because all samples measured here produced low ${ }^{232} \mathrm{Th}$ signals $(>0.1 \mathrm{~V})$, no tailing corrections on ${ }^{230} \mathrm{Th}$ were necessary. All ages were calculated with Isoplot ${ }^{43} \mathrm{v}$. 3.75 using half-lives from ref. 44 for ${ }^{238} \mathrm{U}$ and ref. 45 for ${ }^{234} \mathrm{U}$ and ${ }^{230} \mathrm{Th}$.

\section{References}

1. van Zanten, B.T., van Beukering, P.J., \& Wagtendonk, A.J. Coastal protection by coral reefs: A framework for spatial assessment and economic valuation. Ocean Coast. Manage. 96, 94-103 (2014).

2. Blanchon, P., Granados-Corea, M., Abbey, E., Braga, J.C., Braithwaite, C., Kennedy, D.M., Spencer, T., Webster, J.M. and Woodroffe, C.D. Postglacial Fringing-Reef to Barrier-Reef conversion on Tahiti links Darwin's reef types. Sci. Rep. 4, 4997; 10.1038/srep04997 (2014).

3. Yi, S., Sun, W., Heki, K., \& Qian, A. An increase in the rate of global mean sea level rise since 2010. Geophys. Res. Lett. 42, 3998-4006 (2015).

4. Vermeer, M., \& Rahmstorf, S. Global sea level linked to global temperature. Proc. Nat. Acad. Sci. 106, 21527-21532 (2009).

5. Gardner, T.A., Côté, I.M., Gill, J.A., Grant, A., \& Watkinson, A.R. Long-term region-wide declines in Caribbean corals. Science 301, 958-960 (2003).

6. Sheppard, C., Dixon, D.J., Gourlay, M., Sheppard, A., \& Payet, R. Coral mortality increases wave energy reaching shores protected by reef flats: examples from the Seychelles. Estuarine, Coast. Shelf Sci. 64, 223-234 (2005). 
7. Scoffin T.P. Taphonomy of coral reefs: a review. Coral Reefs 11:57-77 (1992).

8. Houk, P., \& Van Woesik, R. Coral assemblages and reef growth in the Commonwealth of the Northern Mariana Islands (Western Pacific Ocean). Mar. Ecol. 31, 318-329 (2010).

9. Blanchon, P., Jones, B., \& Kalbfleisch, W. Anatomy of a fringing reef around Grand Cayman; storm rubble, not coral framework. J. Sediment. Res. 67, 1-16 (1997).

10. Spencer, T. Potentialities, uncertainties and complexities in the response of coral reefs to future sea-level rise. Earth Surf. Proc. Land. 20, 49-64 (1995).

11. Blanchon, P., Jones, B., \& Ford, D.C. Discovery of a submerged relic reef and shoreline off Grand Cayman: further support for an early Holocene jump in sea level. Sediment. Geol. 147, 253-270 (2002).

12. Lighty, R. G., Macintyre, I. G., \& Stuckenrath, R. (1982). Acropora palmata reef framework: a reliable indicator of sea level in the western Atlantic for the past 10,000 years. Coral Reefs 1, 125-130.

13. Blanchon, P., \& Shaw, J. (1995). Reef drowning during the last deglaciation: evidence for catastrophic sea-level rise and ice-sheet collapse. Geology 23, 4-8.

14.Webster J.M., et al. Drowning of the $-150 \mathrm{~m}$ reef off Hawaii: A casualty of global meltwater pulse 1A? Geology 32, 249-252 (2004).

15. Deschamps, P., et al. Ice-sheet collapse and sea-level rise at the Bolling warming 14,600 years ago. Nature 483, 559-564 (2012).

16. Banks, K.W. et al. Geomorphology of the southeast Florida continental reef tract (Miami-Dade, Broward, and Palm Beach counties, USA). Coral Reefs 26, 617-633 (2007).

17. Rodríguez-Martínez, R.E., Jordan-Garza, A.G., Maldonado, M.A., \& Blanchon, P. Controls on coral-ground development along the Northern Mesoamerican Reef Tract. PloS One 6, e28461; 10.1371/journal.pone.0028461 (2011).

18. Blanchon, P., \& Perry, C.T. Taphonomic differentiation of Acropora palmata facies in cores from Campeche Bank Reefs, Gulf of Mexico. Sedimentology 51, 53-76 (2004).

19. Hijma, M.P. et al. A protocol for a geological sea-level database. In Handbook of Sea-Level Research (ed. Shennan, I., Long, A.J., \& Horton, B.P.) 536-553 (John Wiley, Chichester 2015).

20. Lambeck, K., Rouby, H., Purcell, A., Sun, Y., \& Sambridge, M. Sea level and global ice volumes from the Last Glacial Maximum to the Holocene. Proc. Nat. Acad. Sci. 111, 15296-15303 (2014).

21. Bard, E., Hamelin, B., \& Fairbanks, R.G. U-Th ages obtained by mass spectrometry in corals from Barbados: sea level during the past 130,000 years. Nature 346, 456-458 (1990).

22. Toscano, M.A., \& Macintyre, I.G. Corrected western Atlantic sea-level curve for the last 11,000 years based on calibrated $14 \mathrm{C}$ dates from Acropora palmata framework and intertidal mangrove peat. Coral reefs 22, 257-270 (2003).

23. Done T.J. Coral reef, definition. In Encyclopedia of Modern Coral Reefs: Structure Form and Process. Encyclopedia of Earth Science Series (ed. Hopley D.) 261-267 (Springer, Berlin 2011).

24. Lighty, R.G., Macintyre I.G. \& Stuckenrath R. Submerged early Holocene barrier reef south-east Florida shelf. Nature 276, 59-60 (1978).

25. Hubbard, D.K., Gill, I.P., Burke, R.B., \& Morelock, J. Holocene reef backstepping - southwestern Puerto Rico shelf. In Proc. 8th Int. Coral Reef Symp. 2, 1779-1784 (1997). 
26. Leclerc, F.N. et al. The Holocene drowned reef of Les Saintes plateau as witness of a long-term tectonic subsidence along the Lesser Antilles volcanic arc in Guadeloupe. Mar. Geol. 355, 115-135 (2014).

27. Woodroffe, C.D. et al. Response of coral reefs to climate change: Expansion and demise of the southernmost Pacific coral reef. Geophys. Res. Lett. 37, L15602 (2010).

28. Gregoire, L.J., Payne, A.J., \& Valdes, P.J. Deglacial rapid sea level rises caused by ice-sheet saddle collapses. Nature 487, 219-222 (2012).

29. Blanchon P. Meltwater pulses. In Encyclopedia of Modern Coral Reefs: Structure, Form and Process. Encyclopedia of Earth Science Series (ed. Hopley D.) 683-690 (Springer, Berlin 2011).

30. Hanebuth, T., Stattegger, K., \& Grootes, P.M. Rapid flooding of the Sunda Shelf: a late-glacial sea-level record. Science 288, 1033-1035 (2000).

31. Fairbanks, R.G. A 17, 000-year glacio-eustatic sea level record: influence of glacial melting rates on the Younger Dryas event and deep-ocean circulation. Nature 342, 637-642 (1989)

32. Glynn, P.W., Druffel, E.M., \& Dunbar, R.B. A dead Central American coral reef tract: possible link with the Little Ice Age. J. Mar. Res. 41, 605-637 (1983).

33. Reimer, P.J., et al. IntCal13 and Marine 13 radiocarbon age calibration curves, 0-50,000 years Cal. BP. Radiocarbon 55, 1869-1887 (2013).

34. Stathakopoulos, A., \& Riegl, B.M. Accretion history of mid-Holocene coral reefs from the southeast Florida continental reef tract, USA. Coral Reefs 34, 173-187 (2015).

35. Hubbard, D.K. Sedimentation as a control of reef development: St. Croix, USVI. Coral reefs 5, 117-125. (1986).

36. Rogers, C.S. Responses of coral reefs and reef organisms to sedimentation. Mar. Ecol. Prog. Ser. 62, 185-202 (1990).

37. Stocker, T.F., et al. Technical Summary. In Climate Change 2013. The Physical Science Basis. Working Group I Contribution to the Fifth Assessment Report of the Intergovernmental Panel on Climate Change. (IPCC.) 33-115 (Cambridge University Press 2013).

38. Mumby, P.J., Hastings, A., \& Edwards, H.J. Thresholds and the resilience of Caribbean coral reefs. Nature 450, 98-101 (2007).

39. Perry, C. T., et al. Caribbean-wide decline in carbonate production threatens coral reef growth. Nat. Commun. 4, 1402 (2013)

40. Cerdeira-Estrada, S., et al. Benthic habitat and bathymetry mapping of shallow waters in Puerto Morelos reefs using remote sensing with a physics based data processing. Proc. Geosci. Remote Sens. Symp. (IGARSS). 2012 IEEE Int. 22-27 July 2012. Munich, Germany, p. 4383- 4386 (2012)

41. Coronado C., Candela J., Iglesias-Prieto R., Sheinbaum J., López M., Ocampo-Torres F.J. On the circulation in the Puerto Morelos fringing reef lagoon, Coral Reefs 26, 149-163 (2007).

42. Hernández-Mendiola, E., Bernal, J.P., Lounejeva, E., Mortimer, G.E. \& McCulloch, M.T. U-series dating of carbonates using inductively coupled plasma-quadrupole mass spectrometry. Quat. Geochron. 6, 564-573 (2011).

43. Ludwig, K.R. Users manual for Isoplot/Ex. Ver 3.75. Berkeley Geochronology Center Special publication No. 1a, Berkeley, CA, (2012).

44. Jaffey, A. H., Flynn, K. F., Glendenin, L. E., Bentley, W.C. \& Essling A.M. Precision measurement of half-lives and specific activities of $235 \mathrm{U}$ and $238 \mathrm{U}$. Physical Review C 4, 1889-1906 (1971). 
45. Cheng, H. et al. Improvements in ${ }^{230} \mathrm{Th}$ dating, ${ }^{230} \mathrm{Th}$ and ${ }^{234} \mathrm{U}$ half-life values, and $\mathrm{U}-\mathrm{Th}$ isotopic measurements by multi-collector inductively coupled plasma mass spectrometry. Earth and Planet. Sci. Lett. 371-372, 82-91 (2013).

\section{Acknowledgements}

We thank Edgar Escalante of the UASA Academic Meteorological and Oceanographic Monitoring Service (SAMMO) for help collecting the bathymetric data, and Captain Amoury Mendoza, Fernando Negrete, Esmeralda Perez, Miguel A. Perez, and Roxane Laroche for help coring.

\section{Contributions}

$\mathrm{PB}, \mathrm{JE}$ initiated the study, collected the geological data, and $>15 \mathrm{~m}$ bathymetric data. J-PB dated the samples, SC-E, RM-D collected the $<15 \mathrm{~m}$ bathymetric data, SR analysed and rendered the bathymetry, PB analysed the data and wrote the manuscript. All authors contributed to the editing of the manuscript. 